\title{
LOKASI BERTELUR PENYU DI PANTAI TIMUR KABUPATEN MINAHASA PROVINSI SULAWESI UTARA
}

\author{
(Sea Turtle Nesting Site on the East Coast of Minahasa regency, \\ North Sulawesi) \\ Petros Kasenda ${ }^{1^{*}}$, Farnis B. Boneka ${ }^{1}$, Billy. T. Wagey ${ }^{1}$. \\ ${ }^{1}$ Program Studi IImu Kelautan, Fakultas Perikanan dan IImu Kelautan, Universitas Sam \\ Ratulangi, Manado \\ *e-mail :petros.kasenda@gmail.com
}

Today almost all countries and conservation agencies in the world officially banned illegal trade of sea turtle exploitation. Sea turtle has been listed in the list of Appendix I of the Convention International Trade in Endangered Species of Flora and Fauna (Convention on International Trade of Endangered Species - CITES). Sea turtles in danger of extinction due to having degradation of nesting site. Sea turtle nesting site have not been well documented in the East Coast of Minahasa so the need for research on sea turtle nesting. Researching was conducted to map and describe the locations where turtles lay their eggs on the East Coast of Minahasa regency, North Sulawesi. Data obtained by survey and interview residents who live in the vicinity of the study, covering three districts, namely District Kombi, Lembean Eastern District, and District Kakas. Beach nesting site found in Ranowangko, Kawis Beach, Beach Toloun, Kolongan Beach, Beach Lembean, Kamenti, Atep Oki, Parentek, and Tumpaan Beach. Almost all of the same turtle nesting conditions, ie with long coastlines dominated by the white sand and extensive intertidal areas are seagrass at some locations. Most of the residents living in the vicinity of nesting turtles never catch turtles, take eggs for consumption even sell it.

Keywords : Nesting site, egg, sea turtle

Hampir semua negara dan lembaga-lembaga konservasi resmi di dunia melarang perdagangan eksploitasi penyu. Penyu telah terdaftar dalam daftar Apendik I Konvensi Perdagangan Internasional Flora dan Fauna Spesies Terancam (Convention on International Trade of Endangered Species - CITES). Penyu terancam bahaya kepunahan karena tempat bertelur penyu mengalami degradasi. Tempat bertelur penyu belum terdokumentasikan dengan baik di Sulawesi Utara sehingga perlu penelitian tentang lokasi bertelur penyu. Penelitian dimaksudkan untuk memetakan dan mendeskripsikan lokasi tempat bertelur penyu di Pantai Timur Kabupaten Minahasa, Provinsi Sulawesi Utara. Data diperoleh dengan survei dan wawancara warga yang tinggal di sekitar lokasi penelitian, mencakup Tiga wilayah kecamatan yaitu Kecamatan Kombi, Kecamatan Lembean Timur, dan Kecamatan Kakas. Hasil menemukan bahwa tempat bertelur terdapat di Pantai Ranowangko, Pantai Kawis, Pantai Toloun, Pantai Kolongan, Pantai Lembean, Kamenti, Atep Oki, Parentek, dan Pantai Tumpaan. Hampir semua kondisi lokasi bertelur penyu memiliki karakteristik yang mirip, yaitu garis pantainya yang panjang dengan di dominasi oleh pasir putih, daerah intertidal yang luas serta terdapat lamun. Sebagian besar penduduk yang tinggal di sekitar lokasi bertelur penyu pernah menangkap penyu, mengambil telur untuk dikonsumsi bahkan menjualnya.

Kata kunci : Lokasi bertelur, telur, penyu

\section{PENDAHULUAN}

Wilayah perairan Sulawesi Utara merupakan salah satu daerah penyebaran penyu di Indonesia. Penyu kerap ditemukan di perairan Sulawesi Utara antara lain di kawasan Taman Nasional Bunaken, Selat Lembeh, perairan Tumpaan, Likupang, Kombi dan beberapa daerah pesisir lain di Minahasa, 
Bolaang Mongondow serta Kepulauan Sangihe dan Talaud. Dari tujuh jenis penyu yang masih tersisa hingga kini, ada enam jenis yang ditemukan di Indonesia yaitu penyu hijau (Chelonia mydas), penyu sisik (Eretmochelys imbricata), penyu lekang (Lapidochelys olivacea), penyu pipih (Natator depressus), penyu tempayan (Caretta caretta) dan penyu belimbing (Dermochelys coriacea), (Romimohtarto dan Juana, 2001).

Musim bertelur penyu terjadi sepanjang tahun, tiap penyu akan bertelur sekitar 4 sampai 6 kali setiap tahunnya dengan interval masa peneluran selama 12 sampai 14 hari. Meskipun demikian, pada musim-musim tertentu, biasanya selama 2 sampai 5 bulan dalam setahun terjadi aktivitas penyu bertelur melimpah. Di Indonesia produksi paling melimpah terjadi pada musim kemarau, yaitu antara bulan Juli dan Oktober (Binarung, 2011).

Salm dan Halim (1984) dalam Dahuri (2003) mencatat lebih kurang 143 lokasi peneluran penyu yang tersebar di seluruh Indonesia. Tetapi banyak di antara lokasi lokasi peneluran penyu yang luas telah ditinggalkan oleh penyu, karena kondisi lingkungan yang rusak. Ancaman utama terhadap populasi penyu adalah kegiatan manusia, seperti pencemaran pantai dan laut; perusakan habitat peneluran, perusakan daerah mencari

\section{Volume 2 Nomor 1 Tahun 2013}

makan, gangguan pada jalur migrasi; serta penangkapan induk penyu secara ilegal dan pengumpulan telur. Dalam kaitan dengan pengawasan secara Internasional, semua jenis penyu telah dikategorikan sebagai satwa langka dan dilindungi dalam Red Data Book IUCN dan seluruh jens penyu sudah termasuk dalam Appendix 1 CITIES (Rustadi, 2011). Dalam kaitan dengan pengelolaan populasi penyu di masa yang akan datang, prioritas utama pengelolaannya diarahkan pada perlindungan jenis penyu mencakup perlindungan lokasi bertelur, meningkatkan penelitian terhadap perkembangan dinamika populasi, biologi, analisis DNA, sosial ekonomi, dan melaksanakan program penyuluhan terpadu serta membangun jaringan kerja antar negara yang memiliki sumberdaya penyu (Dahuri, 2003).

\section{METODE PENELITIAN}

Penelitian ini dilaksanakan di Pantai timur Kabupaten Minahasa, mencakup wilayah Kecamatan Kombi, Lembean Timur, Kakas, dan Langowan Timur yang memiliki daerah pantai. Jumlah wilayah yang di survey mencakup lebih 20 dusun/desa (Gambar 1). Kegiatan penelitian dilaksanakan dari bulan Januari hingga Mei 2012.

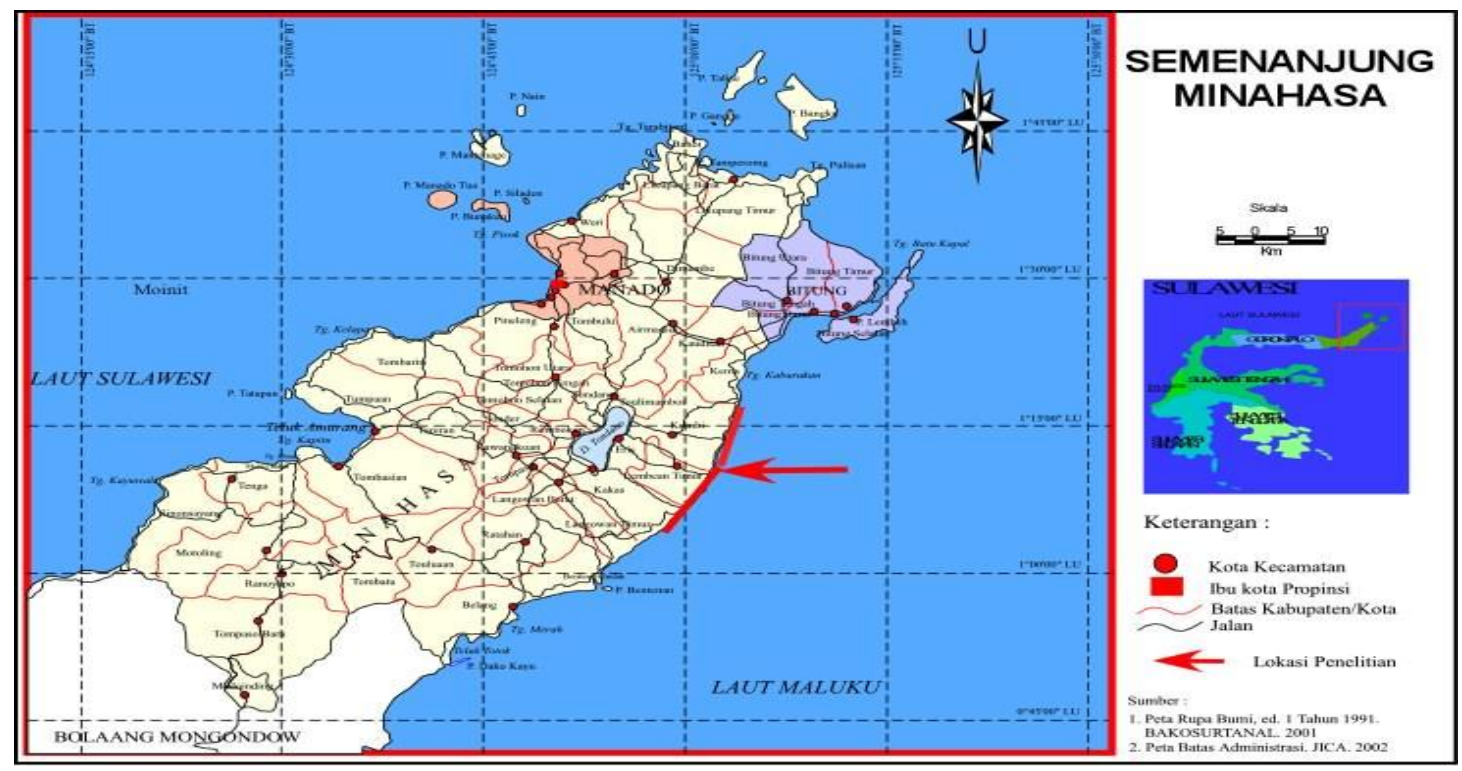

Gambar 1. Lokasi Penelitian 
Tabel 1. Lokasi Bertelur Penyu

\begin{tabular}{|c|c|c|c|c|}
\hline No & Lokasi & Posis Geografis & Kecamatan/Desa & $\begin{array}{c}\text { Waktu } \\
\text { terlihat } \\
\text { Terakhir }\end{array}$ \\
\hline 1 & Pantai Ranowangko & $\begin{array}{l}1^{\circ} 16^{\circ} 01.67^{\prime \prime} \mathrm{LU} \text { dan } \\
125^{\circ} 03 \text { '27.62” BT }\end{array}$ & Kombi/Ranowangko & April 2012 \\
\hline 2 & Pantai Kawis & $\begin{array}{l}1^{\circ} 15^{\prime} 16,37^{\prime \prime} \mathrm{LU} \text { dan } \\
125^{\circ} 02^{\prime} 15.46^{\prime \prime} \mathrm{BT}\end{array}$ & Kombi/Tulap & April 2012 \\
\hline 3 & Pantai Toloun & $\begin{array}{l}1^{\circ} 14^{\prime} 15.24^{\prime \prime} \mathrm{LU} \text { dan } \\
125^{\circ} 03^{\prime} 00.46^{\prime \prime} \mathrm{BT}\end{array}$ & Kombi/Lalumpe & April 2012 \\
\hline 4 & Pantai Kolongan & $\begin{array}{l}1^{\circ} 17^{\prime} 01^{\prime \prime} \mathrm{LU} \text { dan } \\
125^{\circ} 03^{\prime} 45.06^{\prime} \text { ' BT }\end{array}$ & Kombi/Kolongan & Mei 2012 \\
\hline 5 & Pantai Lembean & $\begin{array}{l}1^{\circ} 13^{\prime} 13,36^{\prime \prime} \mathrm{LU} \text { dan } \\
125^{\circ} 02^{\prime} 49,26^{\prime \prime} \mathrm{BT}\end{array}$ & Lembean Timur/Kapataran & Mei 2012 \\
\hline 6 & Kamenti & $\begin{array}{l}1^{\circ} 12^{\prime} 55,98^{\prime \prime} \mathrm{LU} \text { dan } \\
125^{\circ} 02^{\prime} 43,90^{\prime} \text { BT }\end{array}$ & Lembean Timur/Larumis & Mei 2012 \\
\hline 7 & Atep Oki & $\begin{array}{l}1^{\circ} 11^{\prime} 49,36^{\prime \prime} \mathrm{LU} \text { dan } \\
125^{\circ} 02 \text { '18,04' BT }\end{array}$ & Lembean Timur/Atep Oki & Mei 2012 \\
\hline 8 & Parentek & $\begin{array}{l}1^{\circ} 10^{\prime} 53,80^{\prime \prime} \mathrm{LU} \text { dan } \\
125^{\circ} 02^{\prime} 05,37^{\prime} \text { BT }\end{array}$ & Lembean Timur/Parentek & Mei 2012 \\
\hline 9 & Pantai Tumpaan & $\begin{array}{l}1^{\circ} 08^{\prime} 58,45^{\prime \prime} \mathrm{LU} \text { dan } \\
125^{\circ} 01^{\prime} 22,15^{\prime} \text { 'BT }\end{array}$ & Kakas/Tumpaan & Mei 2012 \\
\hline
\end{tabular}

Pengambilan data dilakukan dengan mengunakan metode survey dan mewawancarai masyarakat di dusun desa pesisir Pantai Timur Kabupaten Minahasa. Wawancara dilakukan dengan menggunakan kuisioner tertutup dan perlengkapan dan pilihan jawaban yang telah tersedia.

Data hasil survei diperoleh melalui kuisioner mencakup posisi geografis tempat bertelur penyu dengan menggunakan GPS (Global Position Sistem), status lahan sekitar, vegetasi dominan, habitat pasang surut, kondisi pantai, jarak dengan pemukiman penduduk, dan seberapa sering masyarakat menangkap dan mengkonsumsi daging atau telur penyu. Sedangkan untuk data sekunder mencakup peta, literatur dan peraturan Pemerintah atau yang dikeluarkan oleh lembaga Internasional terkait dengan konservasi penyu. Data ditabulasi, diolah dan dianalisis. Deskripsi ini meliputi uraian verbal, tabulasi, peta atau sketsa dan histogram.

\section{HASIL DAN PEMBAHASAN}

Lokasi bertelur penyu di Pantai Timur Kabupaten Minahasa ditemukan pada Pantai Ranowangko, Pantai Kawis, Pantai Toloun, Pantai Kolongan, Pantai Lembean, Kamenti, Atep Oki, Parentek, dan Pantai Tumpaan (Tabel 1).

Tabel 1 menggambarkan sembilan lokasi dimana ditemukan penyu bertelur. Sembilan lokasi tersebut termasuk dalam tiga kecamatan, yaitu Kecamatan Kombi, Lembean Timur, dan Kakas dengan posisi garis $1^{\circ} 17^{\prime} 01^{\prime \prime}$ LU dan 12501'22,15" BT. Di Kecamatan Kombi dan Lembean Timur masing - masing terdapat empat lokasi bertelur penyu yang ke semua lokasi di dua kecamatan ini saling berdekatan, sedangkan di Kecamatan Kakas hanya terdapat satu lokasi bertelur, karena di wilayah ini hanya ada beberapa desa/dusun yang berada di pesisir pantai.

Adapun waktu terlihat terakhir penyu bertelur umumnya pada bulan Mei tahun 2012. Ciri-ciri umum sembilan lokasi adalah garis pantai panjang dengan daerah intertidal yang cukup luas serta umumnya ditumbuhi lamun. Lokasi 
Tabel 2. Kondisi lingkungan tempat bertelur penyu

\begin{tabular}{|c|c|c|c|c|c|c|}
\hline No & Lokasi & $\begin{array}{c}\text { Status Lahan } \\
\text { Sekitar }\end{array}$ & $\begin{array}{l}\text { Warna } \\
\text { Pasir }\end{array}$ & $\begin{array}{l}\text { Vegetasi } \\
\text { Darat } \\
\text { Dominan }\end{array}$ & $\begin{array}{c}\text { Vegetasi } \\
\text { Pasut daerah } \\
\text { Intertidal }\end{array}$ & $\begin{array}{l}\text { Kemiringan dan } \\
\text { Lebar Daerah } \\
\text { Intertidal }\end{array}$ \\
\hline 1 & $\begin{array}{l}\text { Pantai } \\
\text { Ranowangko }\end{array}$ & $\begin{array}{l}\text { Pemukiman } \\
\text { penduduk }\end{array}$ & Putih & Pohon kelapa & Lamun & Landai, \pm 50 Meter \\
\hline 2 & Pantai Kawis & $\begin{array}{l}\text { Hutan dan } \\
\text { kawasan wisata }\end{array}$ & Putih & $\begin{array}{l}\text { Pohon Kelapa } \\
\text { dan ilalang }\end{array}$ & Lamun & Landai, \pm 30 Meter \\
\hline 3 & Pantai Toloun & $\begin{array}{l}\text { Pemukiman } \\
\text { nelayan dan } \\
\text { daerah } \\
\text { konservasi }\end{array}$ & Putih & Pohon Kelapa & $\begin{array}{l}\text { Lamun dan } \\
\text { Mangrove }\end{array}$ & Landai, \pm 50 Meter \\
\hline 4 & $\begin{array}{l}\text { Pantai } \\
\text { Kolongan }\end{array}$ & $\begin{array}{l}\text { Pemukiman } \\
\text { Penduduk dan } \\
\text { Jalan Raya }\end{array}$ & Putih & $\begin{array}{l}\text { Pohon Kelapa } \\
\text { dan Ketapang }\end{array}$ & Lamun & Landai, \pm 20 Meter \\
\hline 5 & $\begin{array}{l}\text { Pantai } \\
\text { Lembean }\end{array}$ & $\begin{array}{l}\text { Pemukiman } \\
\text { Penduduk, Jalan } \\
\text { Raya dan Adanya } \\
\text { Pembangunan }\end{array}$ & Putih & $\begin{array}{l}\text { Pohon Kelapa } \\
\text { dan Ketapang }\end{array}$ & Lamun & Landai, \pm 20 Meter \\
\hline 6 & Kamenti & $\begin{array}{l}\text { Pemukiman } \\
\text { Penduduk dan } \\
\text { Jalan Raya }\end{array}$ & Putih & $\begin{array}{l}\text { Pohon Kelapa } \\
\text { dan Ketapang }\end{array}$ & $\begin{array}{l}\text { Lamun, Rawa } \\
\text { Berlumpur, } \\
\text { dan Mangrove }\end{array}$ & Landai, \pm 20 Meter \\
\hline 7 & Atep Oki & $\begin{array}{l}\text { Pemukiman } \\
\text { Penduduk, Jalan } \\
\text { Raya, dan Daerah } \\
\text { Perlindungan Laut }\end{array}$ & $\begin{array}{l}\text { Putih } \\
\text { bercampur } \\
\text { hitam }\end{array}$ & $\begin{array}{l}\text { Pohon Kelapa } \\
\text { dan Ketapang }\end{array}$ & $\begin{array}{l}\text { Lamun, Rawa } \\
\text { Berlumpur, } \\
\text { dan Mangrove }\end{array}$ & Landai, \pm 20 Meter \\
\hline 8 & Parentek & $\begin{array}{l}\text { Pemukiman } \\
\text { Penduduk dan } \\
\text { Jalan Raya }\end{array}$ & Hitam & $\begin{array}{l}\text { Pohon Kelapa } \\
\text { dan Ketapang }\end{array}$ & $\begin{array}{l}\text { Lamun, Rawa } \\
\text { Berlumpur, } \\
\text { dan Mangrove }\end{array}$ & Landai, \pm 20 Meter \\
\hline 9 & $\begin{array}{l}\text { Pantai } \\
\text { Tumpaan }\end{array}$ & $\begin{array}{l}\text { Pemukiman, } \\
\text { Pertanian, Jalan } \\
\text { Raya. }\end{array}$ & Putih & $\begin{array}{l}\text { Pohon Kelapa } \\
\text { dan Ketapang }\end{array}$ & $\begin{array}{l}\text { Lamun, Rawa } \\
\text { Berlumpur, } \\
\text { dan Mangrove }\end{array}$ & Landai, \pm 25 Meter \\
\hline
\end{tabular}

yang seperti ini merupakan habitat atau tempat yang baik untuk penyu bertelur, penyu menyukai pantai yang panjang dan luas dan sepi untuk menggali lubang tempat mereka bertelur (Rumambi, 1994). Salah satu contoh dari tempat atau lokasi penyu meletakan telur adalah Pantai Toloun (Gambar 2).

Gambar 2 menjelaskan salah satu lokasi tempat penyu bertelur, dimana penyu bertelur di sepanjang garis pantai, bahkan sampai ke daerah pemukiman penduduk. Hal ini mengisyaratkan bahwa penduduk yang tinggal di daerah pantai

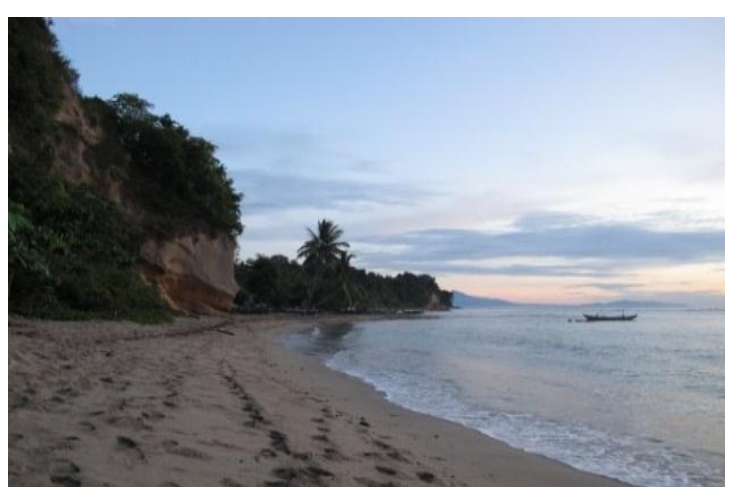

Gambar 2. Pantai Desa Lalumpe/Toloun
Toloun menyadari akan keberadaan penyu itu sendiri.

Ada sembilan lokasi bertelur penyu di Pantai Timur Kabupaten Minahasa dengan kondisi lingkungan tempat penyu bertelur memiliki karakteristik yang hampir sama. Status lahan sekitar dari lokasi penelitian, umumnya wilayah pemukiman, ada beberapa tempat yang digunakan sebagai daerah pariwisata dan daerah konservasi. Pasir putih mendominasi pada pinggiran pantai di delapan lokasi penelitian, sedangkan satu lokasi yaitu Atep Oki yang terdapat pasir putih yang bercampur hitam karena adanya endapan lumpur. Adapun vegetasi darat yang dominan adalah pepohonan kelapa dan ketapang. Vegetasi pasut daerah intertidal didominasi oleh lamun. Kelandaian lebar pantai bervariasi ada yang dari \pm 20 meter sampai \pm 50 meter (Tabel 2).

Adapun hasil wawancara dari responden adalah sebagai berikut. Hasil wawancara menunjukan bahwa warga semua melihat penyu bertelur, dan 
memakan daging dan telur penyu berjumlah 32 responden (100\%), sedangkan untuk informan yang menangkap penyu berjumlah 25 responden $(78,13 \%)$, serta responden yang menjual atau membeli daging penyu berjumlah 3 responden $(9,38 \%)$. Umumnya warga lokal pada saat diwawancara mengungkapkan bahwa mereka menangkap, menjual, membeli dan memakan telur dan daging penyu (Gambar 3).

Dampak dari penetapan daerah konservasi yang dilakukan oleh pemerintah pada tahun 2006 tidak maksimal dan tidak merata. Adanya kesenjangan hubungan antara kepala desa dengan beberapa pengurus desa merupakan salah satu faktor yang mengakibatkan pelestarian ekosistem dan kelangsungan kehidupan penyu terhambat. Salah satu contoh kesenjangan yang terjadi pada beberapa desa pesisir adalah pengelolaan keuangan dari desa menuju kelompokkelompok masyarakat yang terdapat di dusun-dusun desa yang ada di wilayah pantai, dana pengelolaan yang disalurkan pemerintah Kabupaten menuju Kecamatan lancar, begitu juga dana pengelolaan dari Kecamatan ke desadesa juga lancar, akan tetapi ada dana pengelolaan dari desa menuju ke dusundusun pesisir terhambat karena adanya peraturan-peraturan dari desa setempat.

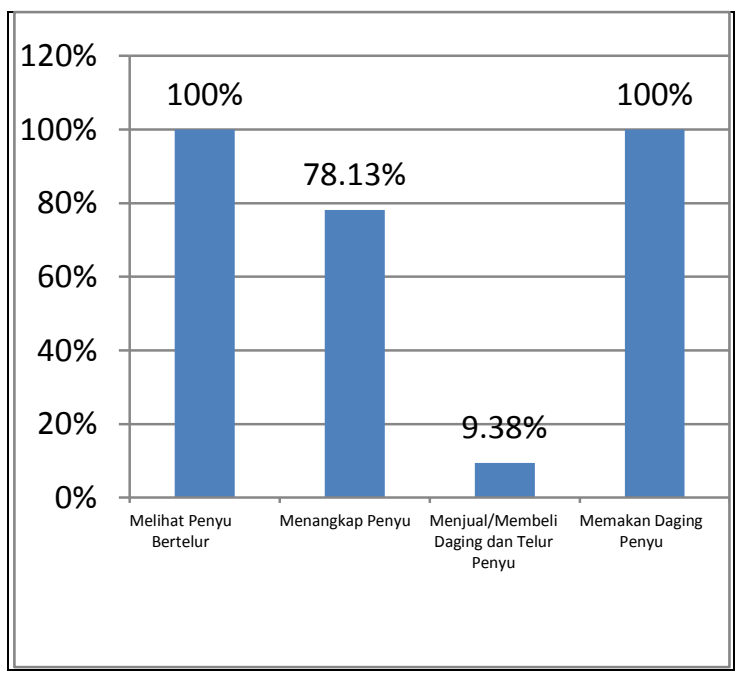

Gambar 3. Persentasi Pengalaman Warga Dengan Penyu.

\section{KESIMPULAN}

Lokasi bertelur penyu di wilayah Kabupaten Minahasa terdapat di Kecamatan Kombi, Lembean Timur, dan Kakas dengan posisi garis $1^{\circ} 17^{\prime} 01^{\prime \prime}$ LU dan $125^{\circ} 01^{\prime} 22,15^{\prime \prime}$ BT, dengan lokasi berada di Pantai Ranowangko, Pantai Kawis, Pantai Toloun, Pantai Kolongan, Pantai Lembean, Kamenti, Atep Oki, Parentek, dan Pantai Tumpaan.

Ciri-ciri umum sembilan lokasi adalah garis pantai panjang dengan daerah intertidal yang cukup luas serta umumnya ditumbuhi lamun dengan kondisi daerah sekitar umumnya wilayah pemukiman, ada beberapa tempat yang digunakan sebagai daerah pariwisata dan daerah konservasi.

Warga melihat dan mengkonsumsi daging dan telur penyu dengan kondisi sekarang warga masih menangkap dan mengkonsumsi daging dan telur penyu tidak terlalu melimpah karena sudah adanya peraturan tentang perlindungan penyu.

\section{DAFTAR PUSTAKA}

Binarung, A. 2011. Konservasi Penyu, Sukamade.http://liabinarung.wordpress. com/2011/12/14/konservasi-penyusukamade/

Dahuri, R. 2003. Keanekaragaman Hayati Laut:Aset Pembangunan Berkelanjutan Indonesia. PT.Gramedia Pustaka Utama, Jakarta.

Romimohtarto, K dan S. Juwana. 2001. Biologi Laut: Ilmu pengetahuan tentang biota laut. Djambatan, Jakarta, 540 hal.

Rustadi, 2011. "Reproduksi Penyu". http://penangkaranpenyudiretakilir.blogs pot.com/2011/09/reproduksi-penyu.html.

Rumambi, R. I. 1994. Siklus hidup Penyu Hijau (Chelonia mydas Linn. 1758). Makalah dalam bidang Management Sumberdaya Perairan UNSRAT. Manado 